\title{
CHANGES OF DRUSEN NUMBER AND CENTRAL RETINAL THICKNESS IN AGE-RELATED MACULAR DEGENERATION PATIENTS OVER TWO YEARS
}

\author{
Krešimir Mandić, Nenad Vukojević, Tomislav Jukić, Damir Katušić and Jelena Juri Mandić \\ Clinical Department of Ophthalmology, Zagreb University Hospital Center, \\ School of Medicine, University of Zagreb, Zagreb, Croatia
}

\begin{abstract}
SUMMARY - Age-related macular degeneration (ARMD) is the leading cause of blindness in developed world but there are still much unknown facts about the disease itself. Age, genetic factors and smoking are the three main risk factors for the development of ARMD, but the exact pathophysiological mechanism of the disease remains unknown. Current high resolution optical coherence tomography devices provide ample new information on retinal layers, drusen characteristics and their interaction. In this study, we analyzed 44 eyes with drusiform dry ARMD using high resolution optical coherence tomography over a 2-year period. Our results showed a statistically significant increase in drusen number in both females and males in the 2-year period. On average, increment by 4 and 5 drusen per eye during the 2-year period was recorded in female and male patients with drusiform dry ARMD, respectively. Also, statistical analysis of the central retinal thickness showed that women with drusiform dry ARMD had a statistically significantly thinner macula than their male counterparts.
\end{abstract}

Key words: Macular degeneration, aged; Retinal drusen; Retina; Sex; Male; Female

\section{Introduction}

Age-related macular degeneration (ARMD) is a progressive, multifactorial, neurodegenerative disease and one of the leading causes of blindness in developed world. It is an elderly population disease. Approximately $10 \%$ of the population older than 65 years has some form of ARMD ${ }^{1}$. Older age as the most significant risk factor for ARMD, together with genetic predisposition and smoking, makes favorable conditions for ARMD appearance ${ }^{1-6}$. There are two types of ARMD, nonexudative or dry and exudative or wet one. Dry form of ARMD disorder of macula is characterized by one or more of the following findings: retinal pigment epithelium (RPE) abnormalities and drusen or areas of geographic atrophy. Patients diag-

Correspondence to: Krešimir Mandić, MD, Dobri dol 40, HR10000 Zagreb, Croatia

E-mail: kresimir_mandic@yahoo.com

Received June 14, 2016, accepted June 30, 2016 nosed with dry form of ARMD have mild disturbances in the quality of vision. They may complain of discrete blurring of vision, changed color perception or altered contrast sensitivity. Over years, most patients with dry ARMD remain in dry stage of the disease but notice some degree of disease progression, which may affect their daily activities (car driving, social activities, etc.) and the quality of life ${ }^{7}$. It is still not known for sure what mechanism of vision is worsening in patients remaining in dry form of the disease. On the other hand, if patients with dry form convert to the wet form, they experience significant and rapid worsening of vision due to the formation of neovascular membrane in macula ${ }^{8}$.

Normal function of retinal photoreceptors in macula requires healthy auxiliary structures, RPE, Bruch membrane (BrM) and choroid. RPE cells envelop and phagocytize outer parts of photoreceptors, deliver nutrient for photoreceptors, but also serve as a barrier that protects photoreceptors from unfavorable factors from the choroid. Under RPE lies Bruch membrane, a 
structure made of extracellular matrix and with a similar role as RPE concerning protection of photoreceptors. Drusen, the hallmark of dry form of ARMD, are situated between RPE and Bruch membrane and are mostly made of lipids (40\%) and various proteins ${ }^{9}$. It is still not known for certain which cells participate in the forming of drusen. Some studies suggest that drusen originate from RPE, other suggest that they originate from choriocapillaris, but the most likely option is that both RPE and choroid participate in drusen formation.

Before the optical coherence tomography (OCT) era, drusen were graded upon their width (small, intermediate or large) and appearance (soft, hard or confluent) on color fundus photography or with indirect ophthalmoscopy ${ }^{10}$. Today's high resolution OCT is a fast noninvasive noncontact and most frequently used tool for analyzing macular structure ${ }^{11}$. Compared to standard indirect ophthalmoscopy, it provides much more information on retinal layers and drusen characteristics, e.g., central retinal thickness (CRT), height, width, reflectivity, homogeneity, and photoreceptor and RPE atrophy ${ }^{12,13}$. It is well known that the number of drusen increases over time but we found no study so far to quantify increase in drusen number in patients with dry $\mathrm{ARMD}^{14}$. In a prospective fashion, the present study compared changes in drusen number and CRT in male and female subjects over a period of 2 years.

\section{Patients and Methods}

In our prospective study that lasted for 2 years, we enrolled 44 eyes of 27 patients ( 20 female and 7 male patients) having dry drusiform ARMD. In 17 patients, both eyes (left and right) were enrolled in the trial, while in another 10 patients we enrolled just one eye. Patients diagnosed with drusiform dry ARMD on fundus examination were screened for inclusion criteria. After dilating pupils using 1 drop of tropicamide and 1 drop of phenylephrine hydrochloride at 10-minute interval, we performed OCT scans of macular area. We included eyes in which drusen were confirmed on OCT scan in the absence of wet ARMD signs and if the average quality of scans was 5 or higher. Non-inclusion criteria were any other macular or other eye disease (high myopia, glaucoma, epiretinal membrane, etc.), dense cataract or opaque vitreous causing the scan quality to be lower than 5 . The device used for OCT scanning was Optopol Copernicus. It is an SD OCT with luminescent diode of $840 \mathrm{~nm}$, with 25000 scans in one second, axial resolution of 6 microns and transverse resolution of 12 microns. We scanned drusen using $3 \mathrm{D}, 6 \times 6 \mathrm{~mm}$ macular mode centered on fovea. Two years later, OCT examination was repeated on the same device in the same fashion. Although we graded every drusen for height, width, reflectivity and homogeneity, we were mostly interested in finding out what was the rate of progression in drusen number over 2-year period and if there were any gender differences on comparing CRT.

\section{Statistical analysis}

Descriptive statistics was applied for all variables. In all statistical analyses, the level of significance was set at $\mathrm{p}=0.05$. The study sample consisted of $27 \mathrm{pa}-$ tients, 20 women and seven men. In four of seven male patients, we enrolled just 1 eye each ( 3 right eyes and 1 left eye). Also, only one 1 eye was enrolled in six of 20 female patients (3 right and 3 left eyes). Differences in the number of drusen and CRT before and after 2-year period were tested with pair test for each eye separately. For comparing total drusen number and CRT according to gender at 2-year period we used ANOVA for repeated measurements separately for the right and left eye.

\section{Results}

The study included 27 subjects, 20 female and seven male, mean age $67.86( \pm 8.11)$ and $70( \pm 6.01)$ years, respectively. There was no statistically significant age difference between male and female patients $(t=0.74$, $\mathrm{p}=0.468$ ).

Significant difference was found in drusen number over 2-year period for both the right and left eye. The mean difference for the right eye was 4.17 and for the left eye 5.05. In other words, the mean increase in drusen number in patients with drusiform dry ARMD was 4.17 drusen for the right eye and 5.05 drusen for the left eye over 2-year period (Table 1 ).

There was no statistically significant difference in CRT at 2 years either for the right or for the left eye, although data showed that after 2 -year period the values of CRT for the right eye were somewhat lower and 
Table 1. Descriptive statistics and pair test results for drusen number and central retinal thickness (CRT) in two-year period for both eyes

\begin{tabular}{|l|l|c|c|c|c|c|c|c|}
\hline & & Mean & SD & $\mathrm{n}$ & $\begin{array}{c}\text { Diff. } \\
\text { in 2 years }\end{array}$ & SD Diff. & $\mathrm{T}$ & $\mathrm{p}$ \\
\hline $\begin{array}{l}\text { Right eye } \\
\text { drusen number }\end{array}$ & Initial & 19.39 & 16.03 & & & & & \\
\cline { 2 - 9 } & At 2 years & 23.57 & 20.25 & 23 & -4.17 & 8.12 & -2.46 & 0.022 \\
\hline \multirow{2}{*}{$\begin{array}{l}\text { Left eye } \\
\text { drusen number }\end{array}$} & Initial & 18.67 & 16.17 & & & & & \\
\cline { 2 - 10 } & At 2 years & 23.71 & 20.23 & 21 & -5.05 & 6.14 & -3.76 & 0.001 \\
\hline \multirow{2}{*}{ Right eye CRT } & Initial & 240.36 & 44.11 & & & & & \\
\cline { 2 - 10 } & At 2 years & 238.59 & 32.82 & 22 & 1.77 & 19.23 & 0.43 & 0.670 \\
\hline \multirow{2}{*}{ Left eye CRT } & Initial & 248.16 & 34.98 & & & & & \\
\cline { 2 - 10 } & At 2 years & 252.84 & 40.30 & 19 & -4.68 & 11.88 & -1.72 & 0.103 \\
\hline
\end{tabular}

$\mathrm{CRT}=$ central retinal thickness

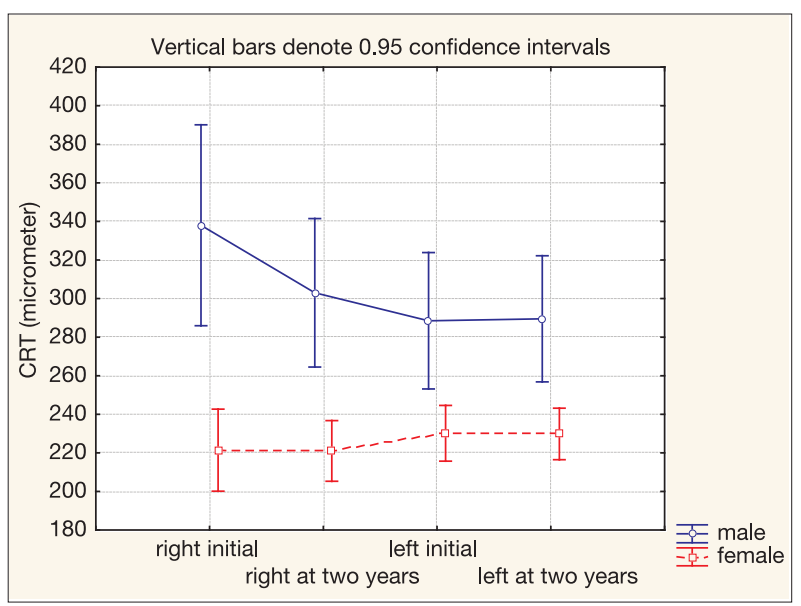

CRT $=$ central retinal thickness

Fig. 1. Diagram of mean and $95 \%$ confidence interval for central retinal thickness (CRT) in both eyes in 2-year period.

for the left eye somewhat higher as compared with the baseline values (Table 1).

Analysis of variance of repeated measurements showed CRT to differ statistically significantly between men and women (Table 2, Fig. 1). Women had a significantly lower CRT irrespective of the eye and time of measurement. Figure 2 shows that $95 \%$ confidence intervals were narrower in women than in men, which can be explained by the predominance of women in the sample. Analysis of CRT showed the interaction between measurement and gender to be statistically significant and indicated that measurements obtained at 2-year interval differed between genders. Not
Table 2. Analysis of variance of repeated measurement for drusen number and central retinal thickness (CRT)

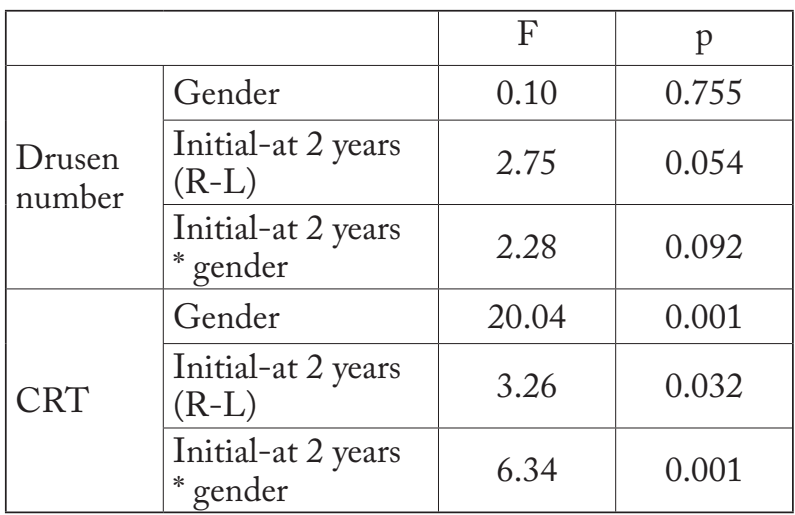

$\mathrm{CRT}=$ central retinal thickness; $\mathrm{R}-\mathrm{L}=$ right-left

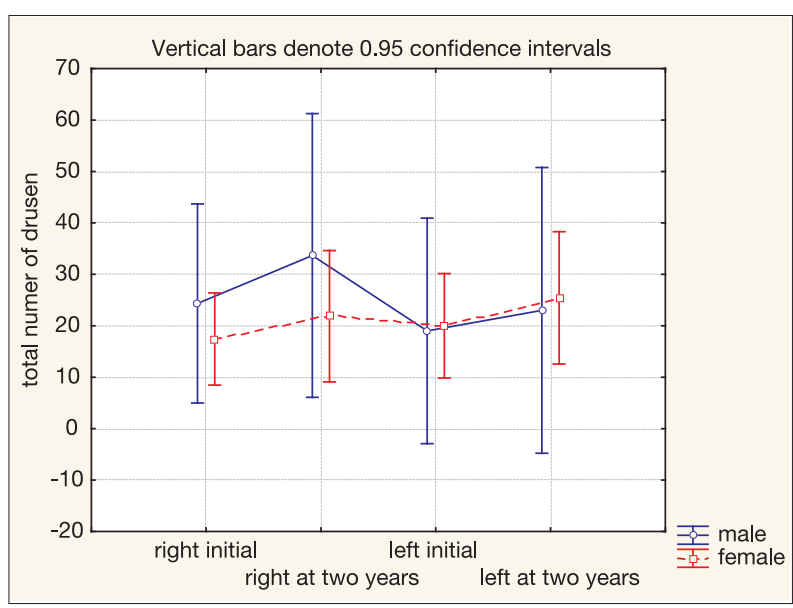

Fig. 2. Diagram of mean and $95 \%$ confidence interval for drusen number for both eyes in 2-year period. 
only that CRT was lower in women but CRT in the left eye showed slight increase as compared to the right eye, whereas in men the results were opposite, i.e. CRT was lower in the left eye than in the right eye.

Concerning difference in drusen number and gender, our data showed no significant gender difference in drusen number. The interaction showed no statistical difference either, pointing out the fact that the number of drusen did not differ according to gender at 2-year interval (Table 2, Fig. 2). However, at 2 years the number of drusen was higher in both eyes.

\section{Discussion}

According to the World Health organization report from 2004, ARMD is the third cause of blindness in the world $(8.7 \%)^{15,16}$. What makes the problem of ARMD even more important is longer life expectancy, especially in developed countries, which implies an increase in the number of ARMD patients. It is estimated that by the year 2040, 288 million people worldwide will have some form of ARMD ${ }^{17}$. Although thousands of reports have been published concerning the course of dry form of disease, still plenty of questions regarding drusen and their behavior over time are waiting to be answered.

Age related disease study 1 and 2 (AREDS 1 and AREDS 2) and other studies before OCT era were very important in terms of sorting out drusen based on their morphological characteristics on fundus photography or indirect ophthalmoscopy and recognizing the ones that are more prone to progress to advanced stages of ARMD (atrophy or wet form). Those studies also acknowledged the benefit of taking high levels of vitamins and antioxidants in patients with dry form of ARMD for postponing disease progression ${ }^{18}$. Unfortunately, at the time of conducting those trials, OCT scans were not included in research and all conclusions on the course and risk factors for disease progression were based upon fundus color photography. Indirect ophthalmoscopy and color photography of fundus are insufficient tools for diagnosing subtle changes in drusen morphology and therefore insufficient for observing drusen changes in dry form of ARMD over time. It was the advent of high resolution OCT devices that started to provide plenty of new information about retinal layers and drusen characteristics. In the past decade, there were a great number of studies that had been investigating the relation of drusen to RPE and various retinal layers. Many of these studies confirmed dynamic changes of drusen over time. Studies with high resolution OCT have discovered that over time drusen may regress, enlarge or stay the same, some drusen may be related to photoreceptor or RPE atrophy, and some studies have confirmed the pre-OCT era studies reporting that a large number of drusen and large diameter of drusen are more likely do lead to advanced stages of $\mathrm{ARMD}^{12,18-21}$. On searching the literature, we found no study that compared changes in drusen number and CRT in patients with dry drusiform ARMD over a period of time.

Our study showed that in a patient with dry form of ARMD, drusen number increased by approximately 4 drusen in the right eye and 5 drusen in the left eye during a 2-year period. This is interesting information because, to the best of our knowledge, the increase in drusen number over years was quantified for the first time. Although drusen may disappear, regress, enlarge, stay the same or completely new drusen may appear with time, we showed that the overall number of drusen in our age group generally increased. The question remains whether this increment in drusen number by itself could be associated with the loss of vision in dry form ARMD or other pathological changes in retina and RPE need to occur as well.

In our study, we also compared CRT between genders and recorded some interesting results. We found that women with drusiform dry ARMD had a statistically significantly thinner macula (CRT) than men. Although we do not know the reason for such a difference, it might be interesting to point out that some earlier researches carried out on healthy subjects also found women to have thinner macula than men. In this context, our result might not be associated to ARMD but rather to being female ${ }^{22-25}$. Some authors argue that thinner macula in women might be attributed to hormonal changes in menopause and even propose that female gender could be a risk factor for other macula diseases such as macular holes ${ }^{26,27}$. In the Beaver Dam Eye Study, macular thickness in women taking oral estrogen was on average $4 \mu \mathrm{m}$ greater than in women not taking oral estrogen, although this difference did not reach statistical significance ${ }^{23}$. This finding may have important implications because difference in thickness between men and women in dry ARMD may have an impact on visual function. Gen- 
der differences in CRT in dry ARMD found in our study should therefore be taken into consideration when performing macular analysis on OCT device. For future studies, it would be interesting to compare CRT and visual acuity between men and women, as well as to compare the rate of progression to advanced stages of disease between genders.

\section{References}

1. Klein R, Cruickshanks KJ, Nash SD, Krantz EM, Nieto FJ, Huang GH, Pankow JS, Klein BE. The prevalence of age-related macular degeneration and associated risk factors. Arch Ophthalmol. 2010 Jun;128(6):750-8. doi: 10.1001/archophthalmol.2010.92

2. Thornton J1, Edwards R, Mitchell P, Harrison RA, Buchan I, Kelly SP. Smoking and age-related macular degeneration: a review of association. Eye (Lond). 2005 Sep;19(9):935-44. doi:10.1038/sj.eye.6701978

3. Loyet KM1, Deforge LE, Katschke KJ Jr, Diehl L, Graham RR, Pao L, Sturgeon L, Lewin-Koh SC, Hollyfield JG, van Lookeren Campagne M. Activation of the alternative complement pathway in vitreous is controlled by genetics in age-related macular degeneration. Invest Ophthalmol Vis Sci. 2012 Sep 25;53(10):6628-37. doi:10.1167/iovs.12-9587

4. Shahid H, Khan JC, Cipriani V, Sepp T, Matharu BK, Bunce C, Harding SP, Clayton DG, Moore AT, Yates JR; Genetic Factors in AMD Study Group. Age-related macular degeneration: the importance of family history as a risk factor. Br J Ophthalmol. 2012 Mar;96(3):427-31. doi: 10.1136/bjophthalmol-2011-300193. Epub 2011 Aug 23

5. Charbel Issa P1, Chong NV, Scholl HP. The significance of the complement system for the pathogenesis of age-related macular degeneration - current evidence and translation into clinical application. Graefes Arch Clin Exp Ophthalmol. 2011 Feb;249(2):163-74. doi: 10.1007/s00417-010-1568-6. Epub 2010 Dec 3

6. Smith W1, Assink J, Klein R, Mitchell P, Klaver CC, Klein BE, Hofman A, Jensen S, Wang JJ, de Jong PT. Risk factors for agerelated macular degeneration: pooled findings from three continents. Ophthalmology. 2001 Apr;108(4):697-704.

7. Gopinath B, Liew G, Burlutsky G, Mitchell P. Age-related macular degeneration and 5-year incidence of impaired activities of daily living. Maturitas. 2014 Mar;77(3):263-6. doi: 10.1016/j.maturitas.2013.12.001. Epub 2013 Dec 14

8. Vrabec R, Vatavuk Z, Benčić G, Čima I, Zrinšćak O, Mandić $Z$. Choroidal neovascularization in age-related macular degeneration treated with photodynamic therapy and intravitreal triamcinolone acetonide. Acta Clin Croat. 2007;46:161-65.

9. Curcio CA, Johnson M, Huang JD, Rudolf M. Aging, age-related macular degeneration, and the response-to-retention of apolipoprotein B-containing lipoproteins. Prog Retin Eye Res.
2009 Nov;28(6):393-422. doi: 10.1016/j.preteyeres.2009.08. 001. Epub 2009 Aug 19

10. Age-Related Eye Disease Study Research Group. A randomized, placebo-controlled, clinical trial of high-dose supplementation with vitamins $\mathrm{C}$ and $\mathrm{E}$, beta carotene, and zinc for agerelated macular degeneration and vision loss: AREDS report no. 8. Arch Ophthalmol. 2001 Oct;119(10):1417-36.

11. Alexandre de Amorim Garcia Filho C, Yehoshua Z, Gregori G, Farah ME, Feuer W, Rosenfeld PJ. Spectral-domain optical coherence tomography imaging of drusenoid pigment epithelial detachments. Retina. 2013 Sep;33(8):1558-66. doi: 10.1097/IAE.0b013e318285cbd2

12. Jain N, Farsiu S, Khanifar AA, Bearelly S, Smith RT, Izatt JA, Toth CA. Quantitative comparison of drusen segmented on SD-OCT versus drusen delineated on color fundus photographs. Invest Ophthalmol Vis Sci. 2010 Oct;51(10):4875-83. doi: 10.1167/iovs.09-4962. Epub 2010 Apr 14.

13. Nathoo NA, Or C, Young M, Chui L, Fallah N, Kirker AW, Albiani DA, Merkur AB, Forooghian F. Optical coherence tomography-based measurement of drusen load predicts development of advanced age-related macular degeneration. Am J Ophthalmol. 2014 Oct;158(4):757-61.e1. doi: 10.1016/j.ajo. 2014.06.021. Epub 2014 Jun 28

14. Yehoshua Z, Wang F, Rosenfeld PJ, Penha FM, Feuer WJ, Gregori G. Natural history of drusen morphology in age-related macular degeneration using spectral domain optical coherence tomography. Ophthalmology. 2011 Dec;118(12):2434-41. doi: 10.1016/j.ophtha.2011.05.008. Epub 2011 Jul 2

15. Resnikoff S, Pascolini D, Etya'ale D, Kocur I, Pararajasegaram R, Pokharel GP, Mariotti SP. Global data on visual impairment in the year 2002. Bull World Health Organ. 2004 Nov;82 (11):844-51.

16. Friedman DS, O’Colmain BJ, Munoz B. Prevalence of age-related macular degeneration in the United States. Arch Ophthalmol. 2004;122:564-72. doi:10.1001/archopht.122.4.564.

17. Wong WL, Su X, Li X, Cheung CM, Klein R, Cheng CY, Wong TY. Global prevalence of age-related macular degeneration and disease burden projection for 2020 and 2040: a systematic review and meta-analysis. Lancet Glob Health. 2014Feb;2(2):e106-16.doi:10.1016/S2214-109X(13)70145-1. Epub 2014 Jan 3

18. Age-Related Eye Disease Study 2 (AREDS2) Research Group, Chew EY, Clemons TE, Sangiovanni JP. Secondary analyses of the effects of luteinl/zeaxanthin on age-related macular degeneration progression: AREDS2 Report No. 3. JAMA Ophthalmol. 2014 Feb;132(2):142-9. doi: 10.1001/jamaophthalmol.2013.7376

19. Wu Z, Luu CD, Ayton LN, Goh JK, Lucci LM, Hubbard WC, Hageman JL, Hageman GS, Guymer RH. Optical coherence tomography-defined changes preceding the development of drusen-associated atrophy in age-related macular degeneration. Ophthalmology. 2014 Dec;121(12):2415-22. doi: 10.1016/j. ophtha.2014.06.034. Epub 2014 Aug 8 
20. Smith RT, Sohrab MA, Pumariega N, Chen Y, Chen J, Lee N, Laine A. Dynamic soft drusen remodelling in age-related macular degeneration. Br J Ophthalmol. 2010 Dec;94(12): 1618-23. doi: 10.1136/bjo.2009.166843. Epub 2010 Jun 7

21. Khanifar AA, Koreishi AF, Izatt JA, Toth CA. Drusen ultrastructure imaging with spectral domain optical coherence tomography in age-related macular degeneration. Ophthalmology. 2008 Nov;115(11):1883-90. doi:10.1016/j.ophtha.2008.04.041

22. Ooto S, Hangai M, Yoshimura N. Effects of sex and age on the normal retinal and choroidal structures on optical coherence tomography. Curr Eye Res. 2015 Feb;40(2):213-25. doi: 10.3109/02713683.2014.952828. Epub 2014 Aug 25

23. Myers CE, Klein BE, Meuer SM, Swift MK, Chandler CS, Huang Y, Gangaputra S, Pak JW, Danis RP, Klein R. Retinal thickness measured by spectral domain optical coherence tomography in eyes without retinal Abnormalities: the Beaver Dam Eye Study. Am J Ophthalmol. 2015 Mar;159(3):445-56. doi: 10.1016/j.ajo.2014.11.025
24. Gupta P, Sidhartha E, Tham YC, Chua DK, Liao J, Cheng CY, Aung T, Wong TY, Cheung CY. Determinants of macular thickness using spectral domain optical coherence tomography in healthy eyes: the Singapore Chinese Eye study. Invest Ophthalmol Vis Sci. 2013 Dec 5;54(13):7968-76. doi: 10.1167/ iovs.13-12436.

25. Adhi M, Aziz S, Muhammad K, Adhi MI. Macular thickness by age and gender in healthy eyes using spectral domain optical coherence tomography. PLoS One. 2012;7(5):e37638. doi: 10.1371/journal.pone.0037638. Epub 2012 May 21.

26. Song WK, Lee SC, Lee ES, Kim CY, Kim SS. Macular thickness variations with sex, age, and axial length in healthy subjects: a spectral domain-optical coherence tomography study. Invest Ophthalmol Vis Sci. 2010 Aug;51(8):3913-8. doi: 10.1167/iovs.09-4189. Epub 2010 Mar 31

27. Evans JR, Schwartz SD, McHugh JD, Thamby-Rajah Y, Hodgson SA, Wormald RP, Gregor ZJ. Systemic risk factors for idiopathic macular holes: a case-control study. Eye (Lond). 1998;12(Pt 2):256-9. doi:10.1038/eye.1998.60

Sažetak

\title{
PROMJENE BROJA DRUZA I SREDIŠNJE MREŽNIČNE DEBLJINE U BOLESNIKA SA SENILNOM MAKULARNOM DEGENERACIJOM KROZ DVIJE GODINE
}

\author{
K. Mandić, N. Vukojević, T. Jukić, D. Katušić i J. Juri Mandić
}

Iako je senilna makularna degeneracija (SMD) vodeći uzrok sljepoće u razvijenom svijetu, još uvijek postoje mnoge nepoznanice oko nastanka i tijeka bolesti. Visoka životna dob, genetska predispozicija i pušenje najvažniji su čimbenici rizika za nastanak bolesti. Moderna optička koherentna tomografija visoke rezolucije (engl. optical coherence tomography, OCT) pruža mnogo novih informacija o retinalnim slojevima, karakteristikama druza i njihovoj uzajamnoj interakciji. U ovom istraživanju usporedili smo nalaze OCT u 44 oka bolesnika koji boluju od suhe druziformne SMD kroz razdoblje od 2 godine. Otkrili smo da se broj druza kroz 2 godine kod žena prosječene dobi od 70 godina uvećao za 4 druze, dok se kod muškaraca prosječne dobi od 68 godina broj druza u istom razdoblju povećao za 5 druza. Uspoređujući centralnu retinalnu debljinu kod muškaraca i žena otkrili smo da žene imaju statistički značajno tanju centralnu retinalnu debljinu od muškaraca.

Ključne riječi: Makularna degeneracija, starija dob; Retina, druze; Retina; Spol; Muška osoba; Ženska osoba 